\title{
Houses for the Poor
}

\section{How Local Culture Supports the Housing for the Urban Poor in Ternate, North Maluku}

\author{
Safrudin Amin ${ }^{1 \text { a }}$, Andi Sumar Karman ${ }^{1}$ \\ ${ }^{1}$ Department of Social Anthropology, Khairun University, Ternate, Indonesia \\ ${ }^{a}$ Corresponding author: safrudinamin@gmail.com
}

\begin{abstract}
In Indonesia, attention to culture as a potential resource for community development has become an important discourse in social policies, community development, and even in academic discourse since the end of 1990s. However, not many evidence have been shown of how the strength the local wisdom is able to contribute significantly to community development. This article, based on our fieldwork, will show one of the real successes of how local wisdom contributes to alleviate urban poverty, to some extent. More specifically, this article explores how Tidore community living in Ternate, based on their local wisdom, build hundreds of livable houses for the urban poor in small city of Ternate. Interestingly, they initiate, plan, finance, and build the houses without support from district, province, or national development budgets. This finding theoretically can contribute to the debate between those who believe that local wisdom does really exist and those who deny its existence. Practically, this finding has potential policy implication in developing culturally-based programs for urban poverty alleviation.
\end{abstract}

Keywords—barifola, housing, local wisdom, tidore, ternate, poor

\section{INTRODUCTION}

One of the oldest academic remarks on housing for the poor appeared in the presentation delivered by John Mann on December 14, 1898 in front of The Philosophical Society of Glasgow forum [1]. Since then, the attention to this issue both at the academic and policy levels has continued to expand and extend to various scientific disciplines. As a result, housing for the poor poor is seen as a multi-faceted phenomenon and can be viewed from different scientific disciplines either jointly or independently.

So far, however, social security mostly has been seen as government's responsibility. Although this view is not wrong, putting too much reliance on the government certainly ignores two important facts. First, governments in many countries, especially developing countries including Indonesia, are unable to cope with all the burdens in poverty alleviation programs. Second, there are some social security mechanisms practiced by civil communities which are intended to reduce the burden of the poor based on local wisdom. This article deals with the second issue mentioned above namely poverty alleviation, especially housing for the urban poor based on local wisdom.
Before going further, it is important to note here that although discourse of local wisdom or other related discourses such as social capital have been circulated widely among development planners, activists, and scholars in universities, the intensity of their spread does not go in line with evidences of success in solving contemporary problems based on the use of cultural wisdoms. It is not surprising that many people, even scholars, doubt about the effectiveness of local wisdom in dealing with modern people's problems [2], [3], [4], [5], [6]. In fact, some do not believe that kind of wisdoms really exist [7], [8]. Even if they might be correct in many respects, their conclusions cannot be generalized. This article will show one case that goes against their conclusion.

This article focuses on the case of local wisdom called barifola which is practiced by Tidore community who lives in the city of Ternate, North Maluku. With this local wisdom, the Tidore community can help finance and build hundreds of decent livable houses for urban poor in Ternate and other cities in North Maluku using their own self-collected funds. From 2008 until 2017, the community has built 190 decent permanent houses for the urban poor from various ethnic backgrounds without sucking up the regional or district government budget (APBD).

Although some studies have shown that there are many local wisdoms among communities in North Maluku [9], [10]. [11], not many of them can survive and remain resilient in facing rapid socio-cultural change, and only few are potential to be revitalized further. In the context of poverty alleviation in north Maluku, barifola, at the present, is the most important example of how a local wisdom is successfully revitalized and organized in order to cope with urban poverty in Ternate. Based on the above description, they questions are how is the context of local wisdom of barifola in the socio-cultural system of the Tidore people? How are the organization and its development? And how is its contribution to the development of livable housing for the poor in Ternate?

\section{RESEARCH METHOD}

\section{A. Location, Sample, and Data Collection}

This article is based on our fieldwork conducted in Ternate city. Informants are chosen purposively. Method employed is 
qualitative ethnography. Data collection techniques are interview, observation, and document analysis.

\section{B. Data Analysis}

There is no standard procedure in qualitative data analysis. However, there is a general agreement that qualitative data analysis begins since data collection begins until research is completed. Data analysis includes data reduction models, data presentation, and drawing conclusions [12].

\section{RESULT AND DISCUSSION}

\section{A. Barifola in Tidorese Culture}

Since the past time, Tidore people have known the tradition of barifola. Barifola consists of two syllables in Tidore language, namely bari and fola. Bari means working together collectively to help someone and fola means house. When the two are combined into barifola, in Tidore culture, it means a kind of mutual assistance activity of Tidore people to build a house.

Along with the development of housing architecture, today houses have taken the form of permanent-concrete houses. Materials, shapes, number of rooms, and size of the rooms are increasingly complex. Consequently, it involves more time and more money to set up a house from beginning until its completion. This led to the change of barifola tradition to be more urban in characters and better organized.

\section{B. Urban Poor and The Birth of Urban Barifola}

Barifola is not only relevant for rural communities. In urban communities like Ternate, where some people cannot afford to get access to suitable dwellings and therefore need assistance, barifola is certainly relevant. Percentage of poverty rate in Ternate in 2015 reached 3,16\%. Although this is the lowest compare with other eight districts under North Maluku Province, the number of poor people behind the lowest percentage is quite many. The poor people in that year were more than 6000 people.

In terms of housing and residential areas, the government of North Maluku Province released data showing that up to 2014, 25,865 housing units $(13.25 \%)$ were categorized as slum dwellings scattered in villages and towns/cities in the province. Among them, a total of 8,779 units (33.94\%) are in the urban and $17,086(66.05 \%)$ located in the rural areas. Regarding housing conditions in the city of Ternate, there were 97.87 percent of houses with non-soil floors (could be cement floor and others) and still 2.13 percent that are soilfloored house.

The figures of poverty above makes barifola appears to be incredibly relevant to the contemporary urban Ternate. The establishment of barifola which is centered in Ternate City cannot be separated from the history of Tidore community organization known as Tidore Family Association (IKT). The organization was founded in 2008. Initially, IKT was intended to prepare savings and loan services for Tidore people, but later was considered less effective. To replace them, the first
IKT chairman, Hi Burhan Abdulrahman (known as Haji Bur) proposed barifola. The meeting was attended by various groups of Tidore community living in Ternate City. The participants of the meeting at that time unanimously agreed on Haji Bur as chairman of IKT. Haji Bur was the then secretary of the City of Ternate and Syamsir Andili as the mayor of the city.

At that time Haji Bur and Syamsir Andili (city mayor)were towards the end of the term of office as important officials in the structure of Ternate city government. Syamsir Andili who had entered the period of the end of his second period as Mayor of Ternate, therefore the city of Ternate at that time required a new mayor, a position that would soon be competed for. Through barifola, haji Bur himself got two satisfactions at once. He felt happy to be able to help his needy fellow Tidore people and gained the sympathy of the citizens of Ternate to vote for him in the Mayoral election later in 2010. The result, as predicted, Haji Bur managed to win the election of Ternate Mayor at that time.

The respected positions of Haji Bur as a Mayor of Ternate elected in 2010 and as an IKT chairman enable him to further intensify the barifola program. The reason, besides being able to donate humanitarian aid (for Tidore people and some nonTidore people in Ternate) he can also fulfill his political interests at once. As a result, he won the mayor election again in 2015 election for his second term. This second term will end in 2021. Those are probably parts of the reasons why barifola among Tidore people was surprisingly revived in urban setting of Ternate City, not back home in the island of Tidore.

\section{Sources of funding and Achievements}

To support this barifola program, IKT initiated and promoted a movement called cala moi (gerakan seribu rupiah) or 'a thousand rupiah movement' which is expected as a source of funds for barifola program. This cala moi movement means that every Tidore family in Ternate city donate their money as much as one thousand rupiah per family. In practice, the contribution received varies from $\mathrm{Rp}$ 200 to 500 thousands. The funding source of the barifola program originally came from the cala moi movement, as mentioned above. It's just that the fund collected from cala $m o i$ is not enough to build a house. Therefore, the first house built through this barifola relied mainly on private funds donated by Haji Bur, the chairman. Since then, fundraising activities for barifola continue to be conducted by IKT board.

The donors for barifola are Tidore people, both living in the city of Ternate or outside of Ternate or even outside North Maluku. In addition, donors from non-Tidore backgrounds are the heads of government units (Dinas or SKPD) and entrepreneurs in Ternate. The contribution from heads of SKPD is not compulsory. They usually come at the time of the execution of the barifola and provide just the cost of drinking water and cigarettes to the people involved in the building construction at that time. They donate an average of $\mathrm{Rp} 500$ thousand. 
Permanent donors for barifola are as many as 98 people with a contribution of $\mathrm{Rp} 250$ thousand per month. Other donors are not specified by the amount of donation, but only according to their ability. Other sources of funding come from the allocation of zakat mal from the Zakat, Infaq, and Sadakah Agency (Badan Amil Zakat, Infaq, dan Sadakah - Bazis) of Ternate. From zakat collected and distributed by Ternate city Bazis, IKT gets some portion for its barifola program. The amount of donation varies according to the amount of zakat mal collected at that time. Along with a fairly high community response, the number of donors also increases over time. Although not mentioned with certainty, the number of donors is seen to increase, both permanent and incidental donors.

Financial supports to the barifola program mainly came from those Tidore residents who are economically already at good level. The various forms of support are in the form of aid or donations, either monthly or incidentally. Incidental support here means financial supports that are given only in certain occasions like Islamic holiday such as idul fitri holiday, or in other events. The donations from Tidore people can come from within North Maluku or from other parts of Indonesia, such as Jakarta.

For ordinary citizens, support is apparent in their participation when the barifola is carried out. By simply joining the IKT as members of barifola team, they feel it has become a great support to barifola. This view arises among themselves because when they become members of barifola team, their activities are not paid at all. It is their contributions to barifola program. For example, carpenters who work on barifola house do not get paid. It is different when he works on other houses outside of the barifola program. Even so, they do not regret joining the barifola team.

As the initial goal, the barifola is intended for helping Tidore people who live in Ternate city. But since the second period of Haji Bur's leadership as mayor of Ternate, barifola aid has reached to people with other ethnic backgrounds as well. Since that time, barifola has targeted other ethnic groups outside Tidore, such as Ternate, Tobelo, Morotai, Makian, and others. As an illustration, as many as 190 units of houses built through the barifola, 22 units are built outside Ternate district.

Barifola has built three units of houses in each of the following districs outside Ternate such as in Tobelo - North Halmahera, Morotai, South Halmahera, Sula, East Halmahera, central Halmahera areas. West Halmahera and Tidore Island, each gets two units. In total, the houses built outside Ternate are 22 units. The rest is built in Ternate in which 35 for nonTidore ethnic backgrounds and 133 units for Tidore people living in Ternate. According to an informant, in the near future they will reach the Mangoli island in Sula.

Now they are targeting more non-Tidore background in order to reach more support from wide varieties of people in North Maluku. Interestingly up to now, some urban poor who are not local ethnic groups also received barifola assistance.

\section{CONCLUSION}

This article briefly cover two issues at once namely urban poverty, especially housing for the urban poor, and local wisdom. This article shows a local best cultural practice in Tidore community that is directed at alleviating the burden of the urban poor especially in terms of improving or building their houses to be livable houses in Ternate.

Barifola is a real example of how local wisdom can be revitalized to be a powerful cultural instrument in dealing with the mounting complexity of urban poverty in this country. Certainly, by saying that it does not mean that barifola or other forms of local wisdom can be the only antidote to urban poverty.

As we have shown that the success of revitalizing or actualizing a local culture to be effective instrument for dealing with urban poverty (or other problems) also depends on some other related factors. First, the cultural item should be able to construct a sense of community among members of a cultural group. Second, following the first, an organization should be established to strengthen the process of cultural revitalization. Third, a leader or an elite should be there as a central figure to attract cultural and emotional support. Fourth, in practical level, proof should be shown to members and to other people through which trust is established and supports will grow "naturally". The last, related to third, it will be more likely to gain success if the elite as a central of the organization and cultural identification is also a powerful government official.

To end with, this finding has potential for theoretical and policy implications. Theoretically it can contribute to the issues and debate between those who believe that local wisdom does exist and can contribute to solve contemporary human problems and those who deny both its existence and its potential contribution. Practically, this finding has potential policy implication in developing culturally-based programs for urban poverty alleviation.

Our next academic and political challenges are how to transform barifola (or other form of local wisdom) as a cultural instrument to be a policy instrument and how the policy instrument should be linked tightly with its cultural roots in order to make it sustainable in dealing with urban housing problems among the urban poor.

\section{ACKNOWLEDGMENT}

We would like to appreciate the Ministry of Research, Technology, and Higher Education as well as Research Unit of Khairun University for financial and administrative support to our study. We also appreciate the important information provided by Mr. Samaun. We thanks Safrudin Abd Rahman dan Bahtiar Hairullah for being involved in data collection process. 


\section{REFERENCES}

[1] M. John, "Better houses for the poor: will they pay? : a paper read to the Philosophical Society of Glasgow ... and to the Scottish Society of Economists, etc". London: LSE Selected Pamphlets. 1899.

[2] N. Gerben, A Matter of Style: Social Security and Livelihood in Upland East Java. PhD thesis, Nijmegen, Dept. of Anthropology, Radboud University Nijmegen, 2003, http://webdoc.ubn.kun.nl/mono/n/nooteboom_g/mattofst.pdf.

[3] N. Gerben, Forgotten people: poverty, risk and social security in Indonesia: the case of the Madurese. (Verhandelingen van het Koninklijk Instituut voor Taal-, Land- en Volkenkunde; No. 296). Leiden: Brill, 2015.

[4] G.J. Aditjondro, "Motambu Tana, Pranata Resolusi Konflik atau Landasan Pelebaran Konflik?,' in Revitalisasi Kearifan lokal, A. Alpha, Ed. Jakarta: ICIP - European Commission, 2007.

[5] A. Irwan and W. Ben, "Harvesting and Housebuilding: Decline and Persistence of Reciprocal Labour in a Javanese Village, 1973-2000," in Ropewalking and Safetynets: Local Ways of Managing Insecurities in Indonesia, K. Juliette and H, Frans, Eds. Leiden: Brill, 2006.
[6] H. Frans and W. Benjamin, "Java; Social Differentiation, Food Production and Agrarian Control", in Agrarian Transformations: Local Processes and the State in Southeast Asia, H. Gillian, T. Andrew and W. Benjamin, Eds. Berkeley: University of California Press, 1989, pp. 235265.

[7] L.P. Samuel, The Rational Peasant, the Political Economy of Rural Society in Vietnam. Berkely: University of Calefornia Press, 1979.

[8] E. Ter, The Myth of the Noble Savage. Berkeley: University of California Press, 2001.

[9] A. Safrudin., M. Arlina, A. S. Karman, Kearifan Lokal dan Model Aktualisasinya Bagi Pembangunan di Maluku Utara, unpublished report, 2009.

[10] A.R. Safruddin, A. Safrudin, and B. Adlan, Identifikasi Nilai-nilai Tradisional Suku Bangsa di Maluku Utara, (Unpublished Research Report), 2008.

[11] S.S. Amanan, Modal Sosial dalam Prilaku Komunitas Tidore. Jakarta: Az-Zahra, 2013.

[12] M. B. Miles, dan A. M. Huberman. Analisis Data Kualitatif. Jakarta: UIPress, 2005. 